\title{
EVALUATION OF PLANT GROWTH-PROMOTING AND BIOPROTECTING RHIZOBACTERIA ON WHEAT CROP
}

\author{
WILMAR C. DA LUZ* \\ Embrapa Trigo, Cx. Postal 451, CEP 99001-970 Passo Fundo, RS, Brasil, e-mail: wilmar@cnpt.embrapa.br
}

(Aceito para publicação 14/05/2001)

LUZ, W.C. DA Evaluation of plant growth-promoting and bioprotecting rhizobacteria on wheat crop. Fitopatologia Brasileira 26:597-600. 2001.

\begin{abstract}
Experiments were carried out under laboratory, growth chamber, and field conditions to evaluate the effect of Plant growth-promoting and bioprotecting rhizobacteria (PGPBR) seed treatment on seed pathogens, seed germination, plant growth, and grain yield of wheat (Triticum aestivum). Most of the PGPBR strongly reduced the recovery of the pathogens from infected wheat seeds. All treatments, except the chemical iprodione + thiram, significantly promoted plant growth over the nontreated control. Psudomonas putida biotype A (11) and P. agglomerans (14) showed the greatest effects. Field experiments, carried out at two locations, indicated that all treatments, except $P$.

of wheat . In Pato Branco, PR, P. putida biotype A (11) and P. putida biotype B (44) presented the best results, both being superior to fungal biological and chemical treatments. In Passo Fundo P. putida biotype A (11) and P. putida biotype B (17 and 44) significantly improved yield over the nontreated control. Yield increases of these three PGPBR were similar to the chemical treatment iprodione + thiram. In Pato Branco, P. putida biotype A (11) and P. putida biotype $\mathrm{B}(17)$, as well as the chemical treatment, provided significant increase over the nontreated control. Yield increases by the PGPBR varied from $18 \%$ to $22 \%$ in Passo Fundo and from $27 \%$ to $28 \%$ in Pato Branco.
\end{abstract} chlororaphis (42), significantly increased seedling emergence

Key words: wheat, Triticum aestivum.

\section{RESUMO}

\section{Avaliação de rhizobactérias promotoras do crescimento e bioprotetoras em trigo}

Experimentos foram realizados em laboratório, em câmara de crescimento e em campo com o objetivo de avaliar o efeito do tratamento de sementes com Rhizobactérias Promotoras de Crescimento de Plantas e Bioproteção (RPCPBs) nos patógenos de sementes, na germinação de sementes, no crescimento de plantas e no rendimento de grãos de trigo (Triticum aestivum). A maioria das RPCPBs reduziu drasticamente a contaminação com fungos patogênicos presentes nas sementes de trigo. Todos os tratamentos, exceto o controle químico, promoveram o crescimento de plantas quando comparados com a testemunha não tratada. Os tratamentos Pseudomonas putida biótipo. A (11) e Pantoea agglomerans (14) apresentaram os melhores efeitos. Experimentos ao nível de campo, em dois locais, indicaram que todos os tratamentos, com exceção de Pseudomonas chlororaphis (42), aumentaram significati- vamente a emergência de plântulas. Em Pato Branco, PR o melhor tratamento foi P. putida biótipo A (11). Em Passo Fundo, P. putida biótipo A (11) e P. putida biótipo B (44) foram os mais eficientes. Os tratamentos $P$. putida biótipo A (11) e P. putida biótipo B (17 e 44) significativamente melhoraram o rendimento de grãos quando comparados com a testemunha não tratada em Passo Fundo. Os aumentos de rendimento dessas três RPCPBs foram similares ao do tratamento químico. Em Pato Branco, $P$. putida biótipo A (11), P. putida biótipo B (17) e o tratamento químico proporcionaram aumentos significativos no rendimento de grãos quando comparados com o da testemunha não tratada. Os aumentos de rendimento devido às RPCBPs variaram entre $18 \%$ e $22 \%$ em Passo Fundo e entre $27 \%$ e $28 \%$ em Pato Branco.

\section{INTRODUCTION}

The most important seed-transmitted pathogenic fungi of wheat [Triticum aestivum (L.) Thell.] in Brazil are: Bipolaris sorokiniana Sacc. in Sorok. (Shoem.), Stagonospora nodorum

$\overline{{ }^{*} \mathrm{CNPq} F e l l o w}$
(Berk) Cast. \& Germ., Drechslera tritici-repentis (Died.), and Fusarium graminearum Schw (Luz et al., 1976; Luz, 1987). A generally recommended practice to protect against these fungi is the fungicide seed treatment. (Recomendações da Comissão Sul-Brasileira de Pesquisa de Trigo - 2000). However, chemical treatment is known to disrupt the natural equilibrium within living microbial communities. In addition, 
chemical pesticides have adverse effect on animal and human health. (Luz, 1996)

Plant growth-promoting and bioprotecting rhizobacteria (PGPBR) are one of the possibilities in overcome these problems. The concept of PGPBR, recently created by Luz et al. (1998), is intended to encompass both PBPR (Plant Bioprotection Promoting Rhizobacteria) (Luz, 1996), which are rhizobacteria that promote the protection against major plant pathogens, and PGPR (Plant Growth Promoting Rhizobacteria (Kloepper \& Schroth, 1978), which are rhizobacteria that promote beneficial effects on plant growth through control of deleterious microorganisms (minor pathogens). Several PGPBR have been studied for protecting wheat seeds in Brazil, and the potential of such microbial agents has already been reported (Luz, 1991, 1993a,b, 1994, 1996; Luz et al., 1998).

The objective of the present study was to evaluate the effect of PGPBR on seed-borne pathogen, growth stimulation, seedling emergence, and grain yield of wheat.

\section{MATERIAL AND METHODS}

Seeds of wheat cultivar Embrapa 24 associated with $B$. sorokiniana, $D$. tritici-repentis, and $F$. graminearum were obtained from the Basic Seed Production Service-Embrapa, Passo Fundo, RS, Brazil. The following PGPBR were used: Pseudomonas putida (Trevisan) Migula biotype B (17 e 44), P. putida biotype A (11), P. fluorescens Migula biotype G (42), Pse. chlororaphis Guignard \& Sauvageau (42), Pantoea agglomerans Gavini (14) (all from Embrapa Trigo, Passo Fundo, RS, Brazil), and Bacillus subtilis Ehrenberg (Kodiak HB, provided by Gustafson Co., Texas, USA at a dosage of $300 \mathrm{~g}$ per $100 \mathrm{~kg}$ of seed). Three checks were used: a nontreated control, a fungal control agent (Trichoderma harzianum Rifai T-22 Planter box, provided by Bioworks, Inc., Geneva, New York, USA), (180 g/100 kg of seed), and a chemical treatment (Iprodione + Thiram $150 \mathrm{~g} / 100 \mathrm{~kg}$ of seeds).

Colonies of each PGPBR were grown on nutrient agar, for $24 \mathrm{~h}$ at $24 \pm 2{ }^{\circ} \mathrm{C}$. Bacterial cells were removed from the surface of the culture media with a brush and placed in sterile distilled water. The concentration of each PGPBR was approximately $10^{7} \mathrm{CFU} / \mathrm{ml}$. A suspension was then applied by dipping the seeds for $3 \mathrm{~min}$ and allowing them to dry at room temperature for $24 \mathrm{~h}$ Nontreated seeds were embedded in sterile distilled water, for $3 \mathrm{~min}$, and allowed to dry. For Kodiak HB, T-22 and iprodione + thiram, the correct amount of product was mixed in a plastic bag by continuous shaking for 3 min until the plastic became clear and the kernels were uniformly coated. For the laboratory experiment, each treatment was replicated four times (at 100 grains, ten grains per plate) and placed under UV light for a photoperiod of 12 $\mathrm{h}$ at $24 \pm 2{ }^{\circ} \mathrm{C}$. The experimental design was completely randomized. The presence of each pathogenic fungi was determined five days after plating on nutrient-agar. Data were expressed as a percentage of pathogens recovered from the plated seeds. The growth promotion experiment was done in growth chamber using the same treatments as its laboratory counterpart. Treatments were applied on noninfected seeds of the wheat cultivar PG1. The experimental design was completely randomized with five replicates of 20 seeds sown, spaced $20 \mathrm{~cm}$ apart in autoclaved soil in aluminum trays. Plant height was evaluated 35 days after planting. The data were subjected to variance analysis and the means were separated by Fisher's LSD test at $\mathrm{p}<0.05$.

Field experiments were carried out at two locations: Passo Fundo, RS, and Pato Branco, PR. Seeds of each treatment were manually sown in plots of 12 rows, $3 \mathrm{~m}$ long. The space between rows was $20 \mathrm{~cm}$ and the amount of seeds was equivalent to $120 \mathrm{~kg}$ per hectare. Fertilizers were used following soil analysis and at recommended dosages of NPK. Treatments in each experiment were arranged in a randomized block design. Emergence was measured 21 days after sowing. At maturity, eight central rows of each plot were harvested and yield was determined by $\mathrm{kg} / \mathrm{ha}$. The data were subjected to variance analysis and the means were separated by Fisher's LSD test $(\mathrm{P}<0.05)$.

\section{RESULTS AND DISCUSSION}

Data from the laboratory experiment (Table l) indicated that nontreated wheat seeds were severely contaminated, showing $10 \%$ of $D$. tritici-repentis, $9 \%$ of $F$. graminearum and $7 \%$ of B. sorokiniana. Most of the PGPBR greatly reduced the recovery of pathogens from infected wheat seeds whereas T. harzianum (T-22) was slightly effective. The treatments $P$. putida biotype B (44 and 17), Pse.chlororaphis (42), and $P$. putida biotype A (11) were equivalent to the chemical treatment, providing the best results against the wheat seed pathogens (Table 1). Little is known about the mechanisms of biocontrol using the isolates of the present work. The following effects have been shown by other isolates: antibiosis, competition, nich exclusion, pathogen adherence, inactivation of fungal propagule stimulants present in the seed exudates and parasitism (Luz, 1996). Antibiotics, however, may be playing the most significant role in this particular experiment.

The effects of PGPBR on plant growth (Table 2) showed that all treatments, except the chemical iprodione + thiram, promoted plant growth when compared with the nontreated control. Psudomonas putida biotype A (11) and $P$. agglomerans (14) showed the greatest effects. These data illustrate another way by which PGPBR act on plants, that is, stimulating direct growth without the presence of pathogens (Kloepper, 1991, 1993; Luz 1996). This may involve mechanisms such as soil mineralization, nitrogen fixation and phytohormones described for several PGPBR (Luz, 1996; Kloepper, 1991; 1993).

Data from field experiments (Tables 3 and 4) showed that both locations, all treatments, except $P$. chlororaphis (42), significantly increased seedling emergence of wheat (Table $3)$. In Pato Branco, the best treatment was $P$. putida biotype A (11). In Passo Fundo, $P$. putida biotype A (11) and $P$. putida 
TABLE 1 - Effect of seed-applied PGPBR on pathogen recovery from infected wheat (Triticum aestivum) seeds. Passo Fundo, RS, Brazil

\begin{tabular}{|c|c|c|c|}
\hline \multirow{2}{*}{ Treatment } & \multicolumn{3}{|c|}{ Recovery ${ }^{1}$ from seeds (\%) } \\
\hline & D.t-r ${ }^{2}$ & F. $\operatorname{gram}^{2}$ & B.s. $^{2}$ \\
\hline Nontreated & $10 \mathrm{~d}$ & $9 \mathrm{~d}$ & 7 \\
\hline Pseudomonas putida biot B (44) & 0 a & 0 a & $1 \mathrm{a}$ \\
\hline P. putida biot A (11) & $0 \mathrm{a}$ & $0 \mathrm{a}$ & $1 \mathrm{a}$ \\
\hline Bacillus subtilis (Kodiak HB) ${ }^{3}$ & $3 \mathrm{~b}$ & $4 \mathrm{~b}$ & $5 \mathrm{~b}$ \\
\hline Pantoea agglomerans (14) & $3 \mathrm{~b}$ & $3 \mathrm{~b}$ & 1 a \\
\hline P. fluorescens biot $\mathrm{G}(42)$ & $2 \mathrm{~b}$ & $3 \mathrm{~b}$ & $4 \mathrm{~b}$ \\
\hline P. putida biot B (17) & $0 \mathrm{a}$ & $0 \mathrm{a}$ & 0 a \\
\hline Trichoderma harzianum (T 22 Planter box $)^{4}$ & $8 \mathrm{c}$ & $7 \mathrm{c}$ & $5 \mathrm{~b}$ \\
\hline P. chloro raphis (42) & $1 \mathrm{a}$ & $2 \mathrm{~b}$ & $1 \mathrm{a}$ \\
\hline Iprodione + thiram $^{5}$ & $0 \mathrm{a}$ & $0 \mathrm{a}$ & $0 \mathrm{a}$ \\
\hline C.V.\% & 2.4 & 3.2 & 2.5 \\
\hline
\end{tabular}

${ }^{1}$ Means of 5 replicates of 100 seeds. Means followed by different letters are different according to Fisher's LSD test at $\mathrm{p}<0.05$.

${ }^{2}$ D.t-r $=$ Drechslera tritici-repentis, F. gram. $=$ Fusarium graminearum. B.s. $=$ Bipolaris sorokiniana.

$3300 \mathrm{~g} / 100 \mathrm{~kg}$ of seeds

${ }^{4} 180 \mathrm{~g} / 100 \mathrm{~kg}$ of seeds

${ }^{5} 150 \mathrm{~g} / 100 \mathrm{~kg}$ of seeds

TABLE 2 - Effect of seed-applied PGPBR on wheat (Triticum aestivum) growth under controlled conditions. Passo Fundo, RS, Brazil

\begin{tabular}{lc}
\hline \hline Treatment & Plant height $^{\mathbf{1}}(\mathbf{c m})$ \\
\hline Nontreated & $26.5 \mathrm{c}$ \\
Pseudomonas putida biot A (11) & $29.6 \mathrm{a}$ \\
P. putida biot B (17) & $28.6 \mathrm{ab}$ \\
P. putida biot B (44) & $28.8 \mathrm{ab}$ \\
P. chlororaphis (42) & $28.2 \mathrm{ab}$ \\
P. fluorescens biot G (42) & $28.9 \mathrm{ab}$ \\
Pantoea agglomerans (14) & $29.2 \mathrm{a}$ \\
Bacillus subtilis (Kodiak HB $)^{2}$ & $27.8 \mathrm{~b}$ \\
Trichoderma harzianum (T 22 Planter box) & $27.7 \mathrm{~b}$ \\
Iprodione + thiram & $26.2 \mathrm{c}$ \\
\hline CV\% & 9.6 \\
\hline
\end{tabular}

${ }^{1}$ Plant height in centimeter of cultivar PG1, 35 days after sowing. Average of 5 replicates. Means followed by different letters are different according to Fisher's LSD test at $\mathrm{p}<0.05$.

${ }^{2} 300 \mathrm{~g} / 100 \mathrm{~kg}$ of seeds

${ }^{3} 180 \mathrm{~g} / 100 \mathrm{~kg}$ of seeds

${ }^{4} 150 \mathrm{~g} / 100 \mathrm{~kg}$ of seeds

biotype B (44) were the best treatments, both being superior to a fungal biocontrol agent and chemical treatment.

The effects of the treatments on wheat grain yield at both locations (Table 4)showed that the treatments $P$. putida biotype A (11), and P. putida biotype B (17 and 44) significantly improved yield over the nontreated control in Passo Fundo. Yield increases of these three biological agents were similar to the chemical treatment iprodione + thiram. In Pato Branco, P. putida biotype A (11) and P. putida biotype B (17), as well as the chemical treatment, provided significant increase over the nontreated control (Table 4). Yield increases by the PGPBRs varied from $18 \%$ to $22 \%$ in Passo Fundo and from $27 \%$ to $28 \%$ in Pato Branco.

In the present experiments PGPBR reduced the population of pathogens associated with seeds, stimulated
TABLE 3 - Effect of seed-applied PGPBR on wheat (Triticum aestivum) seedling emergence under field conditions. Passo Fundo, RS, and Pato Branco, PR, Brazil

\begin{tabular}{|c|c|c|}
\hline \multirow{2}{*}{ Treatment } & \multicolumn{2}{|c|}{ Seedling emergence $^{1}$} \\
\hline & Passo Fundo & Pato Branco \\
\hline Nontreated & $251 \mathrm{~d}$ & $241 \mathrm{~d}$ \\
\hline Pseudomonas putida biot B (44) & $285 \mathrm{a}$ & $263 \mathrm{bc}$ \\
\hline P. putida biot A (11) & $284 \mathrm{a}$ & $276 \mathrm{a}$ \\
\hline Bacillus subtilis (Kodiak HB $)^{2}$ & $272 b$ & $261 \mathrm{bc}$ \\
\hline Pantoea agglomerans (14) & $268 \mathrm{bc}$ & $260 \mathrm{bc}$ \\
\hline P. fluorescens biot $\mathrm{G}(42)$ & $268 \mathrm{bc}$ & $260 \mathrm{bc}$ \\
\hline Pseudomonas putida biot B (17) & $267 \mathrm{bc}$ & $268 \mathrm{ab}$ \\
\hline Trichoderma harzianum (T 22 Planter box $)^{3}$ & $262 \mathrm{bc}$ & $257 \mathrm{bc}$ \\
\hline P. chlororaphis (42) & $258 \mathrm{~cd}$ & $253 \mathrm{~cd}$ \\
\hline Iprodione + thiram $^{4}$ & $269 \mathrm{bc}$ & $263 \mathrm{abc}$ \\
\hline C.V.\% & 3.19 & 3.30 \\
\hline
\end{tabular}

${ }^{1}$ Means of 2 central rows of $3 \mathrm{~m}$. Means followed by different letters are different according to Fisher's LSD test at $\mathrm{p}<0.05$.

${ }^{2} 300 \mathrm{~g} / 100 \mathrm{~kg}$ of seeds

${ }^{3} 180 \mathrm{~g} / 100 \mathrm{~kg}$ of seeds

${ }^{4} 150 \mathrm{~g} / 100 \mathrm{~kg}$ of seeds

TABLE 4 - Effect of seed-applied PGPBR on wheat grain yield under field conditions. Passo Fundo, RS, and Pato Branco, PR, Brazil

\begin{tabular}{|c|c|c|}
\hline \multirow{2}{*}{ Treatment } & \multicolumn{2}{|c|}{ Yield $(\mathrm{kg} / \mathrm{ha})^{1}$} \\
\hline & Passo Fundo & Pato Branco \\
\hline Nontreated & $1817 \mathrm{~b}$ & $1528 \mathrm{~b}$ \\
\hline Pseudomonas putida biot A (11) & $2180 \mathrm{a}$ & 1959 a \\
\hline P. putida biot B (17) & 2135 a & 1938 a \\
\hline P. putida biot B (44) & 2213 a & $1605 \mathrm{~b}$ \\
\hline P. chlororaphis (42) & $1869 \mathrm{~b}$ & $1552 \mathrm{~b}$ \\
\hline P. fluorescens biot G (42) & $1821 \mathrm{~b}$ & $1560 \mathrm{~b}$ \\
\hline Pantoea agglomerans (14) & $1872 \mathrm{~b}$ & $1559 \mathrm{~b}$ \\
\hline Bacillus subtilis (Kodiak HB) ${ }^{2}$ & $1826 \mathrm{~b}$ & $1581 \mathrm{~b}$ \\
\hline Trichoderma harzianum (T-22 Planter box $)^{3}$ & $1873 \mathrm{~b}$ & $1598 \mathrm{~b}$ \\
\hline Iprodione + thiram $^{4}$ & $2277 \mathrm{a}$ & $1938 \mathrm{a}$ \\
\hline $\mathrm{CV} \%$ & 6.5 & 10.3 \\
\hline
\end{tabular}

${ }^{1}$ Means followed by different letters are significantly different according to Fisher's

LSD test at $\mathrm{p}<0.05$.

${ }^{2} 300 \mathrm{~g} / 100 \mathrm{~kg}$ of seeds

${ }^{3} 180 \mathrm{~g} / 100 \mathrm{~kg}$ of seeds

${ }^{4} 150 \mathrm{~g} / 100 \mathrm{~kg}$ of seeds

plant growth, improved seedling emergence, and increased wheat grain yield. Other studies using Paenibacillus macerans Ash (144) and another isolate of P. putida biotype B for wheat seed protection against $D$. tritici-repentis (Luz et al., 1998) provided similar evidence. In that study, T. harzianum presented no significant efficacy against $D$. tritici-repentis under laboratory conditions, but showed wheat yield enhancement (Luz et al., 1998). Similar benefits from $T$. harzianum have been shown in other crops (Harman et al., 1989). Beneficial effects of PGPBR and fungal bioprotectants on plants have been previously reviewed (Bakker et al., 1991; Harman, 1991; Kloepper, 1991, 1993; Luz, 1993b, 1996). Other mechanisms such as hidrocyanic acid, siderophores and induction of resistance may also play a role in the action of PGPBR. Rhizobacterial agents will probably be one of the 
most significant strategies for disease management in the third millennium (Luz, 1996). Therefore, the PGPBR tested in the present experiments are promissing as potential plant growth stimulators and bioprotectants against wheat diseases.

\section{REFERENCES}

BAKKER, P.A.H.M., VAN PEER, R. \& SCHIPPERS, B. Suppression of soil-borne plant pathogens by fluorescent pseudomonads: mechanisms and prospects. In: A.B.R. Beemster, G.L. Bollen, M. Gerlagh, M.A. Ruissen, B. Schippers \& A. Tempel (Eds.) Biotic interactions and soil borne diseases. Eds. Elsevier. Amsterdam. 1991. pp.217-223.

HARMAN, G.E. Seed treatments for biological control of plant disease. Crop Protection 10:166-171. 1991.

HARMAN, G.E., TAYLOR, A.G. \& STASZ, T.E. Combining effective strains od Trichoderma harzianum and soil matrix priming to improve biological seed treatment. Plant Disease 73:631-637. 1989.

KLOEPPER, J.W. Plant growth-promoting rhizobacteria as biological control agents of soilborne diseases. In: J. BayPeterson (Ed.) The biological control of plant diseases. Food and Fertilizer Technological Center. Taiwan. 1991. pp. $142-52$

KLOEPPER, J.W. Plant growth-promoting rhizobacteria as biological control agents. In: Metting, B. (Ed.). Soil microbial technologies. New York, Marcel Dekker, 1993. pp. 255-274.

KLOEPPER, J.W. \& SCHROTH, M.N. Plant growthpromoting rhizobacteria on radishes. In: Procceedings of the fourth international conference on plant pathogenic bacteria, INRA, v.2. 1978. pp. 879-882.

LUZ, W.C. da. Identificação dos principais fungos das sementes de trigo. EMBRAPA-CNPT. Circular Técnica, 1. 1987.

LUZ, W.C. da. Controle biológico das doenças na espermosfera. In: Embrapa-CNPA (Ed.) Controle biológico de doenças de plantas. 1991. pp.25-31.

LUZ, W. C. da. Controle microbiológico do mal-do-pé do trigo pelo tratamento de sementes. Fitopatologia Brasileira 18:82-85. 1993a.

LUZ, W.C. da. Microbiolização de sementes para o controle de doenças das plantas. In: W.C. da Luz, J.M.C. Fernandes, A.M. Prestes \& E.C. Picinini (Eds.). Revisão Anual de Patologia de Plantas. 1993b. pp.35-77.

LUZ, W.C. da. Microbiolização das sementes para o controle da podridão comum das raízes e dos patógenos e seu efeito no rendimento de trigo. Fitopatologia Brasileira 19:144-148.1994.

LUZ, W.C. da. Rizobactérias promotoras de crescimento de plantas e de bioproteção. In: W.C. da Luz, J.M.C. Fernandes, A.M. Prestes \& E.C. Picinini (Eds.). Revisão Anual de Patologia de Plantas. 1996. pp.1-49.

LUZ, W.C. da, LUZZARDI, G.C. \& SANTIAGO, J.C. Importância de Helminthosporium sativum P.K. \& B. em sementes de trigo no Brasil. In: EMBRAPA-CNPT (Ed.) Reunião Anual Conjunta de Pesquisa de Trigo. 1976. pp. 115-129.

LUZ, W.C. da., BERGSTROM, G.C. \& STOCKWELL, C.A. Seed applied bioprotectants for control of seedborne Pyrenophora tritici-repentis and agronomic enhancement of wheat. Canadian Journal of Plant Pathology 20:384-386. 1998.

RECOMENDAÇÔES DA COMISSÃO SUL-BRASILEIRA DE PESQUISA DE TRIGO. In: Anais, XXXII Reunião da Comissão Sul-Brasileira de Pesquisa de Trigo. Cruz Alta. 2000. pp.90. 